\title{
Formation of the Institutional Model of Public Administration of Post-Industrial Transformation of the Ukrainian Industrial Complex
}

\author{
Volodymyr Dykan ${ }^{1}$, Iryna Tokmakova ${ }^{1 *}$, Natalia Kalicheva ${ }^{1}$, Myroslava Korin ${ }^{1}$, Anastasiia Kozlova ${ }^{2}$ \\ ${ }^{1}$ Ukrainian State University of Railway Transport \\ ${ }^{2}$ O.M. Beketov National University of Urban Economy in Kharkiv \\ *Corresponding authorE-mail: it.tokm@ukr.net
}

\begin{abstract}
The analysis of the institutional factors that negatively influenced the activities of the industrial complex of Ukraine in the process of formation of the neo-liberal economy model was performed. It was clarified that the accelerated liberalization of economic relations in Ukraine caused the loss of the core function in ensuring the effective functioning of the industrial sector - management. On the basis of the study of the change of key economic development indicators, the consequences of the crisis in industry were found out. The current conditions of the Ukrainian industrial sector development were described by clarifying such trends as globalization, socialization and humanization, intellectualization and business integration. The conceptual provisions of the institutional model of public administration of the development of the Ukrainian industry on the basis of the post-industrial economy have been formed. The goals, objectives, strategic priorities of the industrial sector development were identified and the promising form of business organization for introduction of high-tech production was determined. The main areas for improving the public administration frame with respect to the regulatory, supporting and coordination components and by forming an effective mechanism of public control were clarified.
\end{abstract}

Keywords: Development; Industrial complex; Institutional factors; Postindustrial economy; Public administration.

\section{Introduction}

The current economic crisis in Ukraine and the serious destructions in the development of the industrial complex confirm the view of many foreign and domestic scientists and practitioners about the ineffectiveness of the economic policy for the country's development, which was chosen at the initial stage of the Ukrainian statehood formation. In fact, the process of socio-economic transformation in Ukraine began with the destruction of the principles and tools of the planned and administrative economy that were still in effect and was accompanied by a complete rejection of government intervention in the processes of socio-economic transformations in the country.

The neoliberal model of the Ukrainian industrial complex development during the years of the country's independence has completely collapsed. Deindustrialization and ousting the domestic commodity manufacturers both from the domestic and the global markets have remained the main trends of the Ukrainian industry. The gradual loss of one of the most powerful during the Soviet times industrial potential is accompanied by a hypertrophied energy and raw material orientation of industrial production, which negatively affects the welfare of the state and in general does not correspond to the logic of the post-industrial society.

The low effectiveness of the market doctrine in ensuring the Ukrainian economy modernization causes institutional failures and traps. Unformed and inefficient, in most cases, the imitative functions of the institutes of the Ukrainian industry development have become the basis for the emergence and spread of crisis phenomena.

\section{Analysis of Scientific Studies and Publications Covering the Topics of Public Administration of Industrial Development in Terms of Post-Industrial Transformations}

The issues of the industrial complex development with postindustrial economic growth have constantly been under scrutiny of many Ukrainian and foreign scientists and specialists. The origins and ways of ensuring industrial revival of the industrial potential of Ukraine lies in the area of the modern concept of post-industrial society, a significant contribution to the deepening of which has been made by such scholars as D. Bell, John Galbraith, P. Drucker, W. Rostow, A. Toffler and others. Significant efforts of these researchers were aimed at the theoretical determining of the postindustrialization phenomenon of and its characteristic features, finding out the impact of technological components and knowledge on economic processes in countries. In particular, D. Bell, clarifying the essence of a post-industrial society from the perspective of such a society, "in the economy of which the priority has shifted from the production of goods to the production of services, research, organization of the education system and improving the quality of life; in which the class of technical experts has become the leading professional group and, most importantly, in which innovation ... is increasingly dependent on achievements 
of theoretical knowledge", has identified the science and theoretical knowledge as the basis for post-industrialization and the growth of services and the role of information - as its features [1]. A similar theory is that of A. Toffler "the third wave superindustrial civilization", which provides for three "waves" of society development, the last of which - the informational one - is characterized by the increase of the knowledge contribution in stimulating economic growth processes [2]. The same is the view of T. Stonier who considered post-industrial economy as that based on the service sector, specialized in the information services for industry, the share of which is very low [3].

Possibilities for post-crisis recovery of the industrial complex of Ukraine have been found in the area of transition to a new technological way, recognition of the leading role of knowledge and information in stimulating innovation transformations in the country. The need to improve the use of technology, informatization and intellectualization of Ukraine's economy, including industrial complex, is indicated in a number of public policy documents such as the Sustainable Development Strategy for Ukraine by 2030, The Strategy of the Development of High-Tech Industries by 2025 , the Concept for the development of Digital Economy and Society in Ukraine for 2018-2020 and approval of the Programme of measures for its implementation, the Concept of the National Target Economic Program for Industrial Development for the period up to 2020 [4 -7].

Among Ukrainian scientists, there is also considerable discussion about finding possible ways for industrial development in terms of post-industrial transformations. A special achievement is the exploratory studies of Yu.V. Kindzersky, who, on the basis of the identified defects of industrial policy of Ukraine and the established structural constraints related to the institutes of state and property, has developed a strategy of structural and technological modernization of industry and defined the measures of the public policy for their implementation. At the heart of structural and technological modernization, according to this scientist, there should be state order and government procurement, activation of innovation and investment activity, formation of integrated structures and improvement of the public administration quality [8].

O.I. Amosha, V.P. Vishnevsky and L.O. Zbarazska have also studied the trends of development and achievements of Ukrainian industry. The team of these scientists has identified prospects of industrial development of Ukraine, which they believe are in the formation of a favourable institutional environment and improvement of the monetary and tax legislation, creation of special development institutions, ensuring accelerated development of research and investment area, the inclusion of Ukrainian industrial enterprises in global value-added chains [9].

L.I. Fedulova has been studying the innovative aspects of the Ukrainian industry development. In her work "Innovative vector of the industry development in Ukraine", she draws attention to the causes and consequences of low innovation activity in the industrial complex of Ukraine, and on this basis she has proposed a sectoral approach to the innovation industrial development strategy [10].

The monograph by V.M. Heyets, L.V. Shynkaruk and T.I. Artyomova is devoted to the clarification of scientific and innovative levers of the industry modernization. A team of these scientists draws attention to the lack in the industry structure of the enterprises capable of implementing technological modernization of industry and the economy as a whole and on its basis to develop the mechanisms for the implementation of public structural policy. The modernization of the Ukrainian industry is proposed through the change in the complex management system, including through the implementation of the project management principles for the development and implementation of industrial policy, the development of innovation infrastructure, the introduction of an efficient system for mobilizing investment resources and their management, promoting innovation research and enhancing the prestige of creative work [11].

According to V.L. Dykan and M.V. Korin, considering the peculiarities of the government regulation of the industrial development in Ukraine, it is possible to achieve qualitative changes in the existing system of industrial production through the transformation of the system of government support and stimulation of industrial development in accordance with the requirements of a high-tech market, namely through the changes in the quality of government regulation tools and the promotion and implementation of the principles of moral and ethical education [12].

Taking into account the scientific and practical relevance of the proposals made by the above scientists regarding modernization and development of the industrial complex of Ukraine, in terms of post-industrial transformations, there is a need for the development of conceptual provisions with respect to the formation of the institutional model of public administration of post-industrial transformation of the Ukrainian industrial complex.

\section{Studies of Issues and Prospects of the Industry Development in Ukraine}

\subsection{Identifying the Trends of Industrial Development in Ukraine}

The chosen neo-liberal economy model with a self-regulating market mechanism designed to align the market's "failures" without proper government intervention fell short of bright expectations of the Ukrainian authorities and led to the launch of stagnation and de-modernization mechanisms in the country. As noted by P.S. Yeshchenko and A.G. Arseenko, "the neoliberal concept played the role of "the detonator in the real economy destruction", forming the basis for the accumulation of fictitious capital through the obtaining not an underlying asset, but profit from price changes..." [13]. As a result, today the production capacities of the industrial complex of Ukraine, in comparison with the pre-reform period, decreased by a hundredfold, increase in the number of bankrupt enterprises and the decrease in the employment rate in the industry has been continuing.

The catalyst for the aggravation of stagnation processes in the industry was those negative consequences of the neo-liberal model of the country's economic development introduced at the beginning of the independence, which launched a mechanism of deindustrial reforms in the industry. The total privatization of industrial enterprises has become the start for transformation of Ukraine into a technologically backward oligarchic state. Changes in the system of ownership of the facilities of industrial plants that were powerful in Soviet-era, without clearly defined "rules" for their implementation, actually reduced to the seizure of enterprises by representatives of the party-economic elite and criminality. The de facto levers of industry management were not in the control of the labor collective as an actor of expression of the workers' interests, but were assigned to enterprise managers, as a rule, in an illegal for this purpose manner. As a result of such a policy of denationalization and corporatization, most of Ukraine's industry was under the control of an illegitimate owner, which was acting solely for the sake of his own gain and in the interests of certain crony groups. According to Yu.V. Kindzersky "there was a phenomenon of the state privatized by oligarchy" [14, P. 78], in which most of the workers of industry and the whole Ukrainian people were in the role of formal participant in "certificate privatization".

Corruption, "fixed deals", raids have become common phenomenon of the transformational period in industry. The lack of proper tools for government protection of business and property rights has led to widespread cases of raids in the country. It will just suffice to mention raider attacks on such industrial giants of Ukraine as PJSC "NVP Saturn", PJSC "Turboatom" and State Enterprise "Electrotyazhmash", accompanied by the appointment of fictitious managers and the violent storming of production and administrative premises. According to the Ukrainian Institute of Research of Extremism, there are currently about 50 professional raider groups operating in Ukraine, causing tremendous damage to the national economy [15]. 
The monopolistic nature of the privatization processes in the industry has increased the technological degradation of the production base of enterprises. The policy of the "illegitimate" owner under the strategy "to get as much as possible while staying in power" became known in the Ukrainian society as the "policy of using up the Soviet legacy" [16, p. 110]. In the area of the production facility recovery, its manifestation was the establishment in the industry of low-tech manufacturing, which, in the absence of real investments from the "so-called" owners in the technological development of enterprises, led to a critical level of the capital consumption of the complex. After all, accumulated investment opportunities were directed not to modernizing the technological industry base, but to protect the "appropriated" assets of enterprises from attacks of criminality. The common phenomenon of the same period of the industry transformation was the phenomenon of the rapid resale of the appropriated public assets. As a result, a significant part of the unique technological equipment was exported or sold as scrap. This kind of barbaric possession, which was focused on obtaining "fast money", led to the disappearance of a number of highly valuable for the country's economy industrial enterprises, the destruction of hundreds of unique industrial enterprises in the former USSR.

Due to the ill-conceived foreign economic policy of liberalization and neglecting by the state of the real industry's needs in the accelerated modernization of production bases, Ukraine lost its status as an industrially powerful state, establishing in the international trade arena the image of the raw materials appendix and the donor for Europe.

The ineffective policy of managing the industrial complex has led to the loss of competitive advantages of domestic industry. The poor quality level and technological backwardness of the production base of most enterprises have caused the displacement of the national producer, even from the domestic trading market, by providing free access to foreign industrial goods. The change in the government foreign trade policy towards the rapprochement and cooperation of Ukraine with the EU also contributed to the overseas expansion of the domestic market of industrial products "Euphoria" of the country's leadership to build Ukraine as a European state in an impulse to break the established production and trade relations with the Eastern partner led to a reassessment of its own potential for industrial development. It turned out that Ukrainian industrial products were far from being competitive, and also were not in demand in a high-tech European market. As a result, not only the traditional markets were lost, but also the industrial facilities and part of the country's territory as a result of the aggravation of military-political confrontation with Russia.

As a result of the ill-conceived policy of neoliberal reforms, which provoked the bankruptcy of hundreds of unique industrial enterprises, the problem of hidden unemployment was exposed, which subsequently led to the loss of highly skilled human resources, including scientists, engineers and skilled workers, and, accordingly, reduced opportunities for innovative development of industry. Referring to statistical data, it should be noted that the personnel outflow from industry was so massive, even shocking in its extent. During the period of 1990-2016, almost 6 million people quitted the domestic industrial complex: in 1990, the number of workers employed in industrial production amounted to 7.8 million people, and in 2016 - 2.5 million people [17, P. 146; 18].

The most painful consequences of neoliberal reforms were for the $\mathrm{R} \& \mathrm{D}$ industry sector. The sharp decline in output and, as a result, a reduction in the level of solvency of industrial enterprises in terms of the outflow of investment resources from the country led to scant amounts of the R \& D financing. In 2000, only 1757.1 million UAH were allocated for innovation activity in industry. [19, p. 68], and in 2015, albeit much more (UAH 13,813.7 million) [20, p. 74], however, in general, it was not enough to intensify innovation in the complex. In fact, by balancing on the verge of bankruptcy and without proper government support (the share of state budget funds for the period from 2000 to 2015 did not exceed $3 \%$ of all expenses for innovation activities of industrial enterprises [19, p. 68], most industrial producers, being aware of too high riskiness of innovation activity, were in no hurry to spend their own funds on the development of innovations. As a result, there was a decrease both in the number of the enterprises involved in the development of innovations and in the amount of created innovative development in the industry. Only in the period 2000-2016, with the increase in the share of industrial enterprises, which introduced innovations from $14.8 \%$ in 2000 to $16.6 \%$ in 2016 (this indicator growth was due to an increase in the number of enterprises that introduced new technological processes and equipment), the production of innovative types of products in the industry decreased significantly and amounted to 4139 items (by comparison, in 2000, 15323 items were introduced). It was the exclusion of sectoral science from the priorities of the economic policy of the country's development that became the main reason for the decrease in the share of the innovative products sold in the total volume of industrial production from $9.4 \%$ in 2000 to $1.4 \%$ in 2015 [18]. The consequences of the neoliberal model of the industrial complex development are given in Fig. 1.

The simulation of the institutions contributed to transforming Ukraine into the poorest country in Europe with deindustrialized production. The way out of the current situation is the transformation of the domestic institutional environment on the moral and spiritual principles with simultaneous implementing promising tools for the industrial capability recovery.

\section{The Clarification of the Prerequisites for the Development of the Industrial Complex of Ukraine and the Development of Guidelines for the Formation of the Institutional Model of Public Administration of the Post- Industrial Transformation of Industry}

The development of Ukrainian industry takes place against the backdrop of significant changes in the world economic environment, caused by the influence of a number of factors and megatrends, among which globalization, socialization and humanization, intellectualization and business integration should be defined. There is no doubt that the future of Ukraine is connected with its ability to skillfully use the globalization processes, since, firstly, the domestic economy is characterized by a significant openness to the overseas world (the value of exports as to GDP steadily exceeds 50\%) [21], and secondly, by aspirations for euro integration, including the progressive country's entry country into the single EU market, and, thirdly, by a radical change in foreign trade relations, which facilitates the intensification of efforts to find new foreign-policy and foreign economic partners and allies. Under these conditions, Ukraine should go in line with world-wide trade trends, timely taking on the latest trends and respectively adapting to them. Currently, Ukrainian industry is integrated in international manufacturing processes on the basis of a rather deformed, asymmetric model, when the hyper-dependence on the foreign markets of semi-finished products is not accompanied by the inclusion in international production networks with regard to the import. 


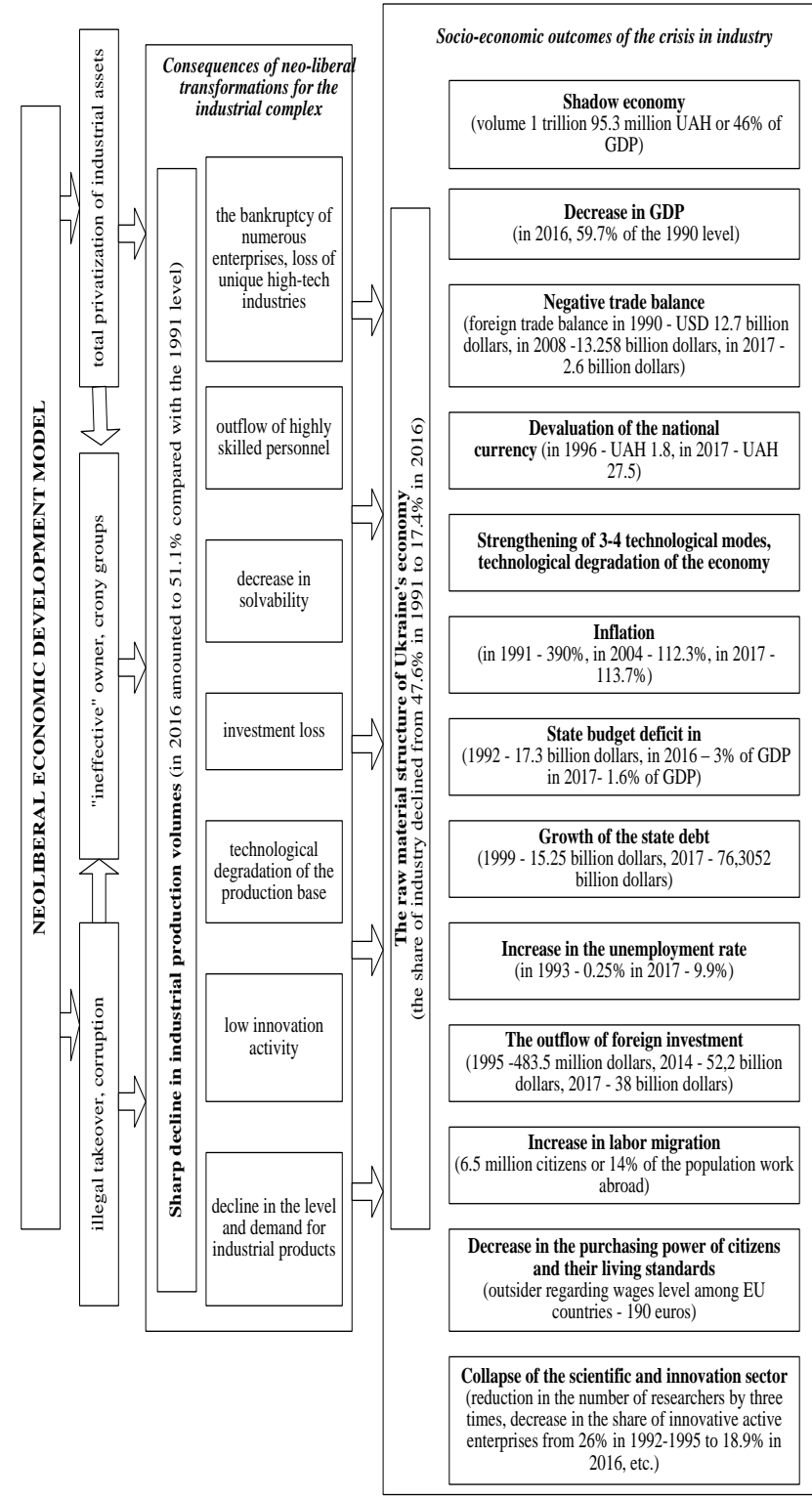

Fig. 1: The consequences of the crisis in the industrial complex of Ukraine.

The universally recognized factors of ensuring sustainable development are the processes of socialization and humanization, since the implementation of economic policy, taking into account only economic and production conditions, does not correspond to the domination of social conditions of economic development, and it turns out to be unproductive. Today, the following parameters of economic policy are at the forefront: taking into account the historical traditions, the spirituality of the population, the system of values, and the level of legal consciousness [22]. The foregoing indicates that the initial component of the institutional transformation of the industrial sector of Ukraine should be the formation of a spiritual and moral basis for the Ukrainian society development. Economic culture and relations should be based on such values as: spiritual commonality, unity, mutual help, mutual understanding, mutual respect, justice, trust, honesty, hard work, but not love of gain, responsibility, efficiency, charity, social security, quality of work. On the basis of spiritual and moral laws and spiritual and moral values, a cultural space is created in which the most important social institutions are formed: state, legal, political, ideological, educational, as well as economic (in particular, norms, rules of economic life, organization of property relations, labour relations, relations of interaction of economic entities), a subsystem of social production is formed, a certain institutional structure of the entire economic system is developed, mechanisms and forms of its functioning, and the management paradigm is also formed. Spiritual and moral values are the basis for ensuring the efficiency of public administration and the development of domestic industry.

Modern economics is becoming more intellectual, since to ensure its growth and competitiveness, it produces, distributes and uses new knowledge. Intellectualization of the economy is directly related to scientific research, applied developments and their implementation, as well as the constant generation and implementation of innovations. The main signs of intellectualization in the industrial sector are deemed to be $[1,3,10]$ : the replacement of an industrial type economy, with the economy based on knowledge and information and the transformation of nature and forms of labor. The new stage in the transformation of industry is described as the fourth industrial revolution (Industry 4.0), which means the development and merging of automated production, the exchange of data and production technologies into a single self-regulated system, with the least or no human intervention in the production process [23]. Hierarchical industry (large firms, holdings) is becoming increasingly heterarchical, networking, the manufacturing sectors are increasingly divided into transformational and transactional, that is, into those producing products and those providing this production. This is the reason for the growing relevance of industrial centres. For the Ukrainian industry, which is characterized by physical and moral wear and tear of productive assets and unfavourable investment climate, the failure to observe the ideology of the fourth industrial revolution will lead to growing gap between it and the leaders of world economic growth.

In solving the tasks of sustainable industry development, with the complication of competitive struggle, an important place is the intensification of integration processes, which allows providing access to technological innovations, reducing information costs, increasing the efficiency of unleashing the potential of relevant resources, overcoming the imbalance of sectoral technological chains, etc. The application of the integration approach in the organization of industrial production allows combining the scientific and technological, innovative and industrial potential of the industry, promotes the creation of a new class of production systems which will pool resources and competencies not available for certain businesses.

The key benefits of implementing the integration policy in industry should be defined as follows [24]:

- structural restructuring of the industrial sector due to the growth of the share of high-tech and high-tech industries, which requires strengthening the role of the government in ensuring the consistency and effectiveness of the implementation of all stages of the innovation process from $\mathrm{R} \& \mathrm{D}$ to commercialization and market introduction of new high value-added products;

- the growth of innovative activity of industrial enterprises due to the development of cooperation between research and production sectors, the development of public-private partnership in the innovation sector, the attraction of highly skilled personnel through the expansion of external relations of enterprises, the development of outsourcing and the growth of investment attractiveness of member companies of networking structures;

- elimination of imbalances in the socio-economic development of the regions and the development of interregional relations through the provision of government support for the creation and development of regional and interregional integration groupings in the sectors with the highest potential of production of goods, competitive in the domestic and foreign markets.

A positive factor is that in Ukraine nominally there are integrated industrial business entities, but their activities do not meet the current requirements, and the transition of the industrial sector to the post-industrial development phase is extremely slow. Thus, the study of trends in the domestic industry development and the modern conditions of their development indicates the need to seek new approaches in the field of management of the industrial complex of Ukraine, which would be aimed at ensuring the sustainable development and competitiveness of the industrial sector (see Fig. 2). 


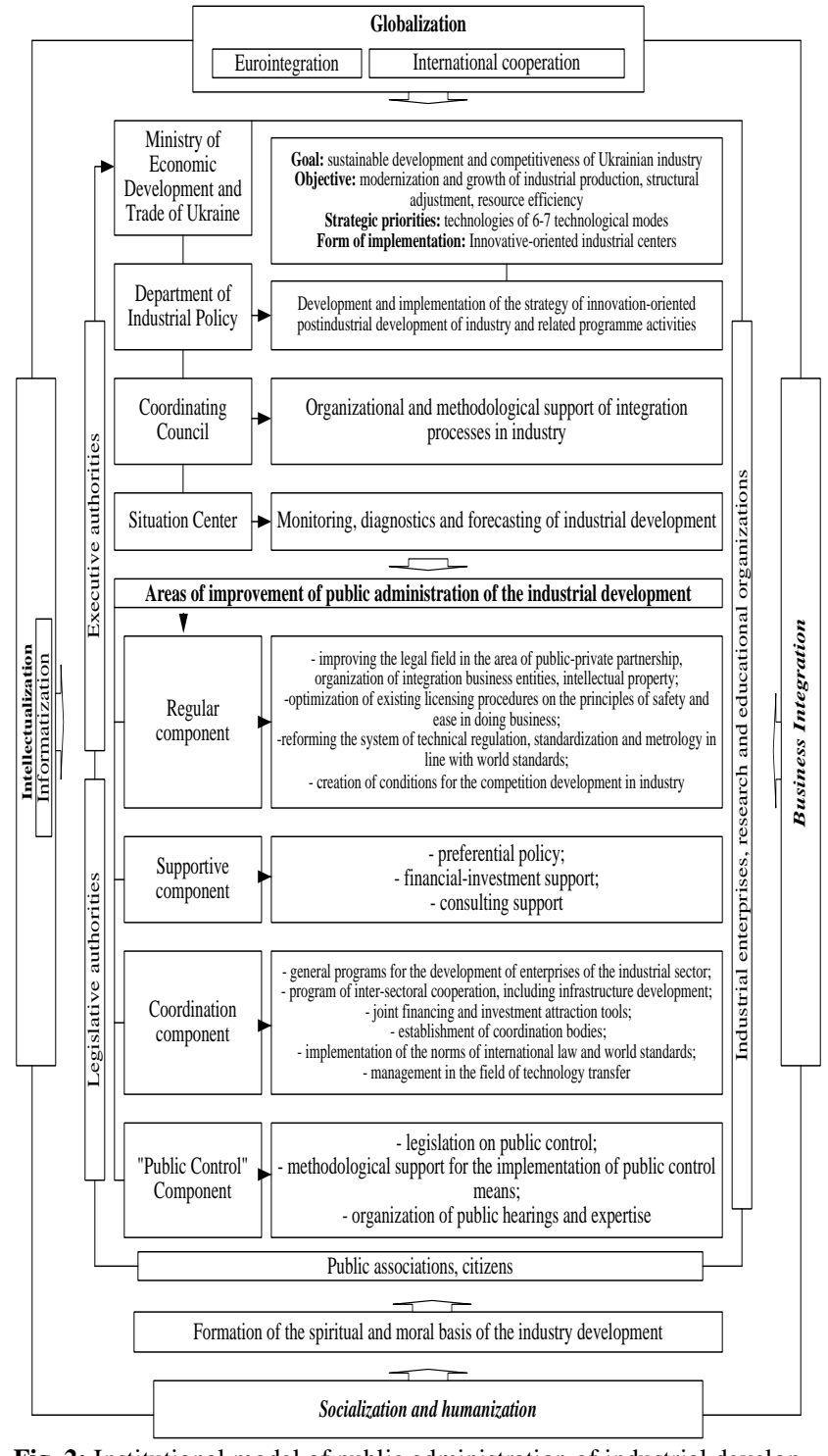

Fig. 2: Institutional model of public administration of industrial development of Ukraine on the basis of post-industrial transformation.

The modernization and growth of industrial production, structural adjustment and resource efficiency have been defined as the key tasks of industrial development are.

The task of modernization and growth of industrial production should be considered in several aspects: the development of existing and the formation of new types of activities with a higher value added; increase in productivity and volumes of industrial production; improvement of management methods; integration into the world value added chains.

Structural adjustment should take place by the industrial capacitybuilding first and foremost through the development of knowledge-intensive industries - mechanical engineering, chemical industry, production of communications, as well as computerization of production, management and services.

More efficient use of resources is extremely relevant for the domestic industrial complex that would reduce their consumption, and this will make the industry more competitive and thereby stimulate the economy and improve the environmental sustainability of the country.

Taking into account the world experience, the strategic priorities of the post-industrial transformation of the Ukrainian industry are connected with the introduction of technologies of 6 and 7 technological modes and include: creation and development of closed production cycles of higher technological modes with high added value, characterized by individualization, nanominiaturization, biotechnologization, cognitivization, application of 3D printing; production of environmentally friendly products, recycling of domestic and industrial waste, introduction of energy- and resource-efficient technologies in industry; exploitation and development of alternative energy sources; development of production of organic food products, etc.

Given the progress of the fourth industrial revolution, the innovation-oriented industrial centres the purpose of which is to combine science and industry to develop new technologies, research and development and to promote innovation industry, should be identified as the promising form of integration business entities in the industrial sector in Ukraine.

It must be acknowledged that the current institutional transformation of the economy takes place through the mechanisms of public-private partnership, which within modern Ukrainian realities are expressed in the formula: more market and more state involvement. Therefore, for implementing the above-mentioned strategic initiatives of the industrial complex development, state authorities should focus on:

1) improving the organization of the economic environment, which needs to improve planning processes in the public administration system and the validity of decisions in the system of government orders;

2) facilitating the self-organization of the economy, including the formation of a highly efficient national innovation system, distribution of integration business models, providing advanced development of business communication means and infrastructure, expanding partnership between the state and business and introduction of the economic dialogue, ensuring transparency in the development and implementation of public policy and strengthening of public control mechanisms.

Based on the principles of spiritual and moral culture, the institutional system of public administration of industrial complex of Ukraine should undergo a series of transformations, among which the changes in the organization of management, regulation, government support, coordination and public scrutiny are of vital importance.

First of all, it is necessary to note the gaps in the organizational component of public administration of the industrial sector, coming from the lack of a coordination mechanism for integration processes and a low level of analytical support for the processes of making managerial decisions. To strengthen the institutional capacity of the Industrial Policy Department of the Ministry of Economic Development and Trade, we propose to create Coordination Council and the Situation Centre within the Ministry of Economic Development and Trade, for ensuring better carrying out the functions entrusted to them, including the development and implementation of the development strategy of the industrial sector of Ukraine.

As for the tools of public administration of industrial development in Ukraine, it requires significant improvement in all its components (regulatory, support and coordination), as well as through the establishment of an effective mechanism of public control.

The regulatory component of public administration of the national industry development must be reshaped with due regard to the best practices, first of all, it is necessary to create powerful investment incentives and attractive environment for enhancing the innovation activities of industrial enterprises. Implementation of this direction includes:

- improvement of the legal field in the area of public-private partnership, organization of integration business entities, intellectual property;

- optimization of existing licensing procedures in the industry, which will ensure a sufficient level of occupational safety control and at the same time an appropriate level of ease of doing business;

- reforming the system of technical regulation, standardization and metrology in accordance with world standards;

- creation of conditions for the competition development in industry.

It is crucial to improve the system of government support for the industry development, which should take place in the following areas: 
- preferential policy;

- financial and investment support;

- consultancy support.

In the matter of implementing supporting functions of the institutional mechanism of public administration of the domestic industry development there are significant shortcomings both in stimulating, and in financial-investment and consultancy.

Today, Ukraine, as never before, needs its own preferential policy with respect to industry. First, for residents of innovation-oriented industrial centres it is necessary to provide special tax privileges, such as: tax holidays; reduced profit tax rate; reduced transport tax rates and insurance premiums; free customs regime; guarantees against unfavourable change of legislation. Secondly, it is necessary to remove industrial investment charges: instalment of import VAT and removal of import duties on all production equipment. Thirdly, it is necessary to revise the rates of duties in the interests of the Ukrainian industry - in order to ensure benefits from the import of the raw materials and components, and from the export of the finished products, and not vice versa.

Also, for the government support of domestic industrial enterprises to be implemented, a new formula for public procurement is urgently needed, according to which the consideration of the local component becomes mandatory. So, if the Ukrainians are paid wages, and the Ukrainian raw materials, materials, components, energy, funds are used in the production of goods, then the price advantage in public procurement should be provided. That is, even if "Ukrainian" products (with a high level of production localization) are slightly more expensive than imported (with a low localization), it will win the tender.

It is necessary to note the existing shortcomings of the implementation of the consultancy support, coming from a significant delay in the introduction of modern communication technologies. There is a digital divide phenomenon in Ukraine, there is no consolidated public strategy for the development of information and communication technologies, which causes slowing the exchange of information, knowledge, experience and technologies.

The dissemination of information on the benefits of implementing resource-efficient technologies should be defined as the key focus of the consultancy support. The implementation of this direction includes: conducting trainings, training courses on energy management and resource efficiency in industry, in particular with the participation of international organizations and international technical assistance projects operating in Ukraine, the involvement of external consultants with specialized resource management and energy efficiency skills; promotion of resource-efficient technologies, raising awareness of the broad benefits that these technologies provide (reducing operating costs and improving competitiveness); creation of sites for the experience exchange, in particular, the creation of a single web portal for publication of tools, information and statistics allowing a real assessment of material and energy production capacity, disseminating the best practices on resource efficiency in industry in sectoral terms; and others. In order to support industrial initiatives and innovations in the field of industry, it is necessary to introduce new and improve existing co-ordination methods with a view to:

- Increasing the effectiveness of cooperation between individual companies, entrepreneurs, research centres, universities and government bodies, the actions of which are aimed at innovation in the field of production;

- Developing transport and logistics, engineering, information, energy and other infrastructure types in terms of promoting the qualitative and quantitative growth of industrial production;

- Integrating into the digital ecosystems and value added chains of partner countries on the basis of the "Industry 4.0" concept. Implementation of coordination activities requires the formation of joint development programs, co-financing and investment attraction tools, the establishment of coordination bodies, the implementation of international law, etc.

Ensuring the efficiency of public administration requires the involvement of the public as a supervisory body, which allows for the consideration of public control as a component of the public administration system. Public control can become an effective means of influencing the development of the industrial sector through the implementation of such areas as holding public hearings and expert assessments regarding industrial policy measures and activities of industrial enterprises and their associations.

\section{Conclusion}

The liberalization of economic relations in Ukraine was accompanied by a significant deformation of the institutional factors supporting the development of the industrial sector, which resulted in the failure to develop of an effective system of public administration, as well as a competitive market and market self-regulation mechanisms, which contributed to the spread of crisis phenomena in the industry. The imitation of social protection, legal privatization, the independent style of public administration, the achievement of sustainable development goals has led to such negative consequences in the Ukrainian industry as the outflow of highly skilled personnel, investment loss, technological degradation, low innovation activity, decline in the level of quality and demand for domestic products, loss of competitiveness, decrease in solvability and massive bankruptcy.

Today, to ensure the development of industry in Ukraine it is necessary to take into account the present-day conditions of economic management in the world, caused by the influence of such key factors as globalization, socialization and humanization, intellectualization and business integration. Their manifestation in a synergistic relationship is reflected in the launch of the Fourth Industrial Revolution and the establishment of a post-industrial society. Under such circumstances, the transformation of the industrial sector of Ukraine is urgently needed, which an effective public administration mechanism is designed to provide. The elaborate conceptual provisions of the institutional model of public administration of the industrial development in Ukraine on the basis of post-industrial modernization include a set of measures aimed at improving the organizational structure of public authorities, reshaping regulatory policy, improving public support, implementing coordination tools and public supervisory mechanisms which taken together will contribute to sustainable development and competitiveness of Ukrainian industry.

\section{Reference}

[1] Bell D., The Coming of Post-Industrial Society: A Venture of Social Forecasting, transl. from English, Moscow, Academia, (1999), p. 956.

[2] Toffler E., Third wave, Moscow, ACT, (1999), p. 784.

[3] Stonier T., The Wealth of Information: a profile of the post-industrial economy, New technocratic wave in the West, ed. by P.S. Gurevich, Moscow, Progress, (1986), p. 450.

[4] The Strategy of Sustainable Development of Ukraine for the Period up to 2030, available online: http://www.ua.undp.org.

[5] The Strategy for the Development of High-Tech Industries by 2025 (2016), available online: http://www.me.gov.ua/Documents/Detail?lang=ukUA\&id=c9b6f0b0-1ed5-4aba-a25e-f824405ccc64\&.

[6] The Concept of the development of the digital economy and society of Ukraine for 2018-2020 and approval of the plan of measures for its implementation (2018), available online: http://zakon5.rada.gov.ua/laws/show/67-2018-\%D1\%80.

[7] Concept of the National Target Economic Program for Industrial Development for the period up to 2020 (2013), available online: http://zakon5.rada.gov.ua/laws/show/603-2013-\%D1\%80.

[8] Kindzersky Yu.V., Industry of Ukraine: Strategy and Policy of Structural and Technological Modernization, monograph, Kyiv, (2013), p. 536

[9] Amosha O.I., Vyshnevsky V.P., Zbarazska L.O. et al., under the general editorship of V.P. Vishnevsky, Industry and Industrial Policy of Ukraine 2013: Current Trends, Challenges, opportunities: science and analytic report, Donetsk, (2014), p. 200.

[10] Fedulova L.I. (2013), Innovative vector of the industry development in Ukraine, Economy of Ukraine 4 (617), 15-23. 
[11] Heyets V.M., Shynkaruk L.V., Artyomova T.I. et al.; ed. by L.V. Shynkaruk, Structural Changes and Economic Development of Ukraine, monograph, Kyiv, (2011), p. 696.

[12] Dykan V.L. \& Korin M.V. (2018), Public Administration of industrial development of Ukraine, Journal of Transport and Industry Economics 61, 9-19.

[13] Yeshchenko P.S. \& Arseenko A.G. (2012), Search for a new paradigm of economic development - a categorical imperative of time, Economic Theory 4, 5-18.

[14] Kindzersky Yu.V., Deindustrial paradox of economic transformations in Ukraine, Ukrainian Journal of Applied Economics, Vol. 2., No. 3, (2017), pp. 74-95.

[15] Mikhailov V. (2014), Announced TOP illegal takeovers in the country of the victorious Maidan, available online: http://uire.org.ua/en/publikatsii/obnarodovan-top-reyderskihzahvatov-v-strane-pobedivshego-maydana/.

[16] Kindzersky Yu.V., Public policy of structural and technological modernization of industry, thesis for a Candidate Degree in Economic Science, specialty 08.00.03, Kyiv, (2015), p. 531.

[17] Nikolayets K.M. (2015), Dynamics and Regional Peculiarities of the Employment of the Ukrainian Population in the 1990s. Journal of Cherkasy University. «Historical Sciences» Series 9 (342), 144148.

[18] Official site of the State Statistics Service of Ukraine, available online: http://www.ukrstat.gov.ua/.

[19] Yepifanova I.Yu. (2012), Analysis of financial support of innovative activity of domestic enterprises in modern conditions, Journal of the National University "Lvivska Polytechnica" Management and Entrepreneurship in Ukraine: Stages of Formation and Issues of the Development 722, 65-70.

[20] Industry of Ukraine in 2011-2015: Statistical Book. Kyiv, (2016), p. 382 .

[21] Sidenko V. (Project Leader) et al., Structural Transformations in the World Economy: Challenges for Ukraine, Analytical Report, Kyiv, Zavet, (2017), p. 182.

[22] Belyaev O.O., Bebelo A.S., Dyba M.I. et al., Economic Policy: study guide, Kyiv, KNEU, (2004), p. 287.

[23] Kramar O. (2016), View from the periphery, Ukrainsky Tyzhden 14 (438), available online: http://tyzhden.ua/Economics/162508.

[24] Sokolenko S.I., Clusters in the global economy: monograph, Kyiv, LOGO, (2004), p. 848. 